\title{
Implementation of the quantitative Real-Time PCR for the molecular-genetic diagnostics of spinal muscular atrophy
}

\author{
O. O. Soloviov, G. B. Livshits, S. S. Podlesnaya, L. A. Livshits
}

Institute of Molecular Biology and Genetics NAS of Ukraine

150, Academician Zabolotnogo Str., Kyiv, Ukraine, 03680

livshits@imbg.org.ua

\begin{abstract}
Aim. To develop an easy and reliable assay for quantitative analysis of the SMN1 gene exon 7 copy number with Real-Time PCR and a SYBR Green dye which can be used as a test-system for spinal muscular atrophy (SMA) diagnostics. Methods. For the quantification the SMN1 gene exon 7 copies we have used the approach, which is based on the comparison of ratio between PCR amplification of the genomic DNA sample and that of an internal standard (Albumin gene) for each subject tested. For the development and validation of the assay we tested the DNA samples from ten patients with SMA (homozygous deletion of the exon 7 in the SMN1 gene) which were previously analyzed using standard PCR-RFLP method and 42 control DNA samples from: 29 heterozygous carriers of the deletion of the exon 7 in the SMN1 gene, 13 individuals without SMN1 deletion, which were previously analyzed using linkage analysis of 2 AE9.1 (D5S557) and LAS96 (D5S681) polymorphic microsatellite loci, and 10 samples from individuals of the general population. The results were calculated using standard Livak method (2 ${ }^{-\Delta \Delta C t}$ method). Results. The mean $\pm S D$ of the $2^{-\Delta \Delta C t}$ ratios for the carriers of the heterozygous deletion of the exon 7 in the SMN1 gene is $0.475 \pm 0.091$; and for the controls $-0.909 \pm 0.068$. The results obtained don't show overlapping between $2^{-\Delta \Delta C t}$ ratios at the carriers of the SMN1 heterozygous deletion and individuals without it $(t=3.84, p>0.05)$. Conclusions. This method can be used as a basis for creating the test-system for SMA DNA diagnostics, especially for the carrier screening.
\end{abstract}

Keywords: spinal muscular atrophy, SMN1 gene, deletion, Real-Time PCR.

Introduction. Spinal muscular atrophy (SMA) is one of the most common autosomal recessive diseases that leads to the anterior horn cells damage. SMA has a frequency of $1 / 6000$ to $1 / 10000$ newborns and a heterozygous carrier frequency of $1 / 40$ to $1 / 50$ [1]. Patients with SMA have been classified into three types on the basis of age of onset and clinical severity (International SMA Consortium 1992): type I (Werding-Hoffman disease) is the most severe form, type II - intermediate form, type III (Kugelberg-Welander disease) is the mildest form [2].

(C) Institute of Molecular Biology and Genetics NAS of Ukraine, 2010
All of these clinical types are caused by homozygous deletion of the exon 7 in the survival motor neuron gene $1(S M N 1)$ that is located in the chromosome region $5 \mathrm{q} 13$. This gene has a highly homologous copy SMN2 that appeared as a result of the duplication of the $5 \mathrm{q} 13$ chromosome region and differs by only five nucleotides [3].

The presence of SMN2 gene does not avoid the SMA symptoms because of a single nucleotide change in the exon 7 that leads to its lacking during the alternative splicing of the mRNA transcripts of the SMN2 gene [5]. No less than $94 \%$ of SMA patients 
have a homozygous deletion of the exon 7 and/or exon 8 in the SMN1 gene [1,3-5]. In Ukraine the frequency of the homozygous deletion in the SMN1 gene among SMA patients is $97.8 \%$ [7]. Minority of SMA patients (2-5\%) have a deletion of the exon 7 in one SMN1 allele and a small intragenic mutation in the other [8].

The homozygous deletion of the exon 7 in the SMN1 gene is easily detected by RFLP [1,7]. Using this analysis the presence or the absence the exon 7 in the $S M N 1$ gene can be determined but it is not possible to estimate the $S M N 1$ copy number. There are methods for semi-quantitative analysis of the $S M N$ copies (e. g. densitometric analysis, gene dosage analysis) but they give procedural errors.

Gene dosage analysis [9] is a method that allows to quantify the number of the $S M N 1$ copies by calculating the peak areas of the radioactively or fluorescently labeled PCR products obtained by fragment analysis. This method needs a number of internal and external standards. However, there is a limitation of the method that can give false positive results due to formation of heteroduplexes between the SMN1 and SMN2 genes. Therefore, this method demands careful choice of the standards [10] .

Detection of the heterozygous deletion carriers in the SMN1 gene is very important for molecular genetic diagnostics due to a high carrier frequency of SMA. Therefore, the aim of our study was to develop an easy and reliable assay for quantitative analysis of the exon 7 SMN1 gene copy number using Real-Time PCR and a SYBR Green dye which can be used as a test-system for the SMA diagnostics.

Materials and Methods. The quantification of the SMN1 gene copies is based on the ratio between the PCR amplification of the genomic DNA sample and that of an internal standard (reference gene with constant copy number) for each subject tested. We have used Albumin gene as reference gene, because it is mostly used in the quantitative Real-Time PCR assays. The results are normalised to the mean of control samples.

For the development and validation of the quantitative analysis of the exon 7 SMN1 gene copy number we tested DNA samples of ten patients with SMA (homozygous deletion carriers of the exon 7 SMNI gene), which were previously analyzed using standard
PCR-RFLP method, their parents and relatives examined with family linkage analysis as heterozygous carriers or individuals without deletion $(n=42)$ and ten individuals from the general population $[1,7,8]$.

DNA isolation and purification from blood samples were done by standard phenol/chloroform procedures [11]. Quantity and quality of DNA probes were determined with ND-1000 spectrophotometer (NanoDrop, USA).

Real-Time PCR quantitative method for the SMN1 gene copy number detection. For the amplification of the exon 7 SMN1 gene (target gene) and the exon $12 A L B$ gene (reference gene) we have synthesized specific oligonucleotide primers using phosphoramidite method on the Biosset ASM800 DNA synthesizer. The primers for the SMN1 gene amplification were designed to detect TTC $>$ TTT transition in the codon 280 of the exon 7 SMNI gene; and, therefore, the primers are specific only to SMN1 gene [6]. The forward primer is 5'-TTTTATTTTCCTTACAGGGTTTC-3'; the reverse primer is 5'GTTTTACATTAACCTTTCAACTTTT-3'. The primers sequences for the amplification of the exon 12 $A L B$ gene described elsewhere [12].

To obtain close efficiency of amplification for those genes, we have determined the optimal concentration of the primers by making a dilution series of $5,10,20 \mu \mathrm{M}$ for each pair of primers. We have determined the optimal cycling conditions for the amplification of target and reference genes that resulted in the lowest $\mathrm{Ct}$ value (threshold cycle) and the highest fluorescence signal and gave no nonspecific products of amplification.

Real-Time PCR was carried out in $25 \mu$ reaction volume containing 12,5 $\mu \mathrm{l}$ of Maxima SYBR Green Master Mix (2x) («Fermentas», Lithuania), $20 \mu \mathrm{M}$ of each SMN1 primer and $5 \mu \mathrm{M}$ of each $A L B$ primer and 15-30 ng of genomic DNA (the volume of the DNA template was no lower than $4 \mu \mathrm{l}$ ). The cycling conditions were following: preincubation $10 \mathrm{~min}$ at $95{ }^{\circ} \mathrm{C}$ to denature the target DNA and activate hot-start iTaq ${ }^{\mathrm{TM}}$ DNA polymerase; 35 cycles of $20 \mathrm{~s}$ at $95^{\circ} \mathrm{C}$ and $50 \mathrm{~s}$ at $60^{\circ} \mathrm{C}$. Amplifications were run in duplicates in separate tubes to permit quantification of the $S M N 1$ gene normalized to the $A L B$ gene. The relative gene copy number $\left(2^{-\Delta \Delta C t}\right.$ ratio) of unknown sample was 


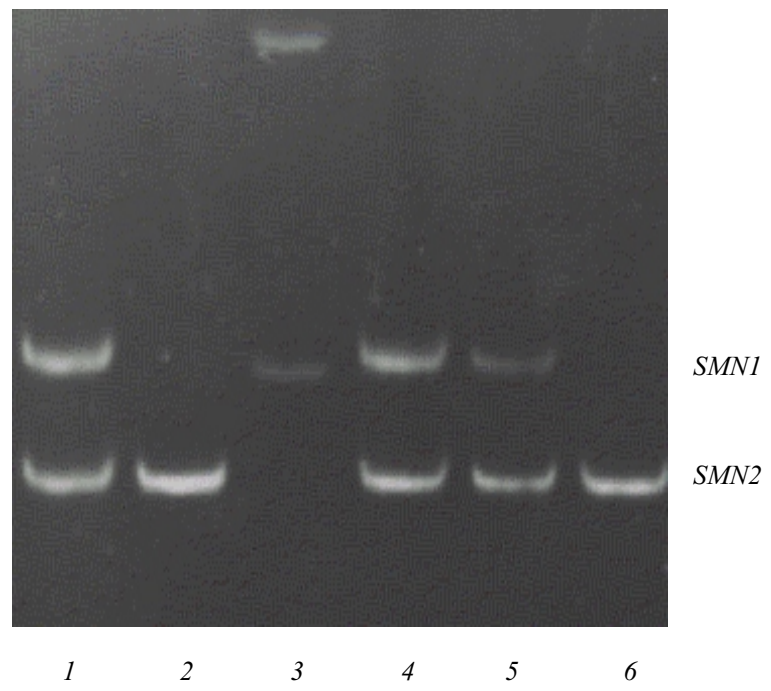

Fig. 1. Detection of the homozygous deletion in the $S M N$ genes using RFLP (digested with DraI, $10 \%$ PAGE): 1 - healthy individual; 4, 5 - parents of the SMA patient without homozygous deletion in the SMN1 gene; 2, 6 - probands with homozygous deletion in the SMN1 gene; 3 - individual with homozygous deletion in the $S M N 2$ gene

estimated using a $2^{-\Delta \Delta C t}$ method (Livak method), because the efficiency of both target and reference genes appear to be near $100 \%$ and within $5 \%$ of each other. The efficiency of Real-Time PCR for both genes was estimated by the calibration using the control DNA samples (data not shown). The steps for calculating the relative copy number using Livak method are following [13]:

$$
\begin{aligned}
& \Delta \mathrm{Ct}_{\text {(test) }}=\mathrm{Ct}_{(S M N I \text { test) }}-\mathrm{Ct}_{(A L B \text { test) }} \\
& \Delta \mathrm{Ct}_{\text {(control) }}=\mathrm{Ct}_{(S M N I \text { control) }}-\mathrm{Ct}_{((A L B \text { control) }} \\
& \Delta \mathrm{Ct}=\Delta \mathrm{Ct}_{\text {(test) }}-\Delta \mathrm{Ct}_{\text {(control) }}
\end{aligned}
$$

Normalized copy number of $S M N 1_{\text {(test) }}=2^{-\Delta \Delta \mathrm{Ct}}$.

The Real-Time data were processed by means of the BIO-RAD iQ5 Optical System Software V 2.0 (2006).

Results and Discussion. The homozygous deletion of the exon 7 was detected in 10 patients using RFLP analysis with DraI. In the Fig. 1 an example of the PAGE of the exon 7 SMN1, 2 genes is shown $[1,7,8]$.

The DNA electrophoretic pattern of the healthy individual looks exactly the same as the DNA patterns

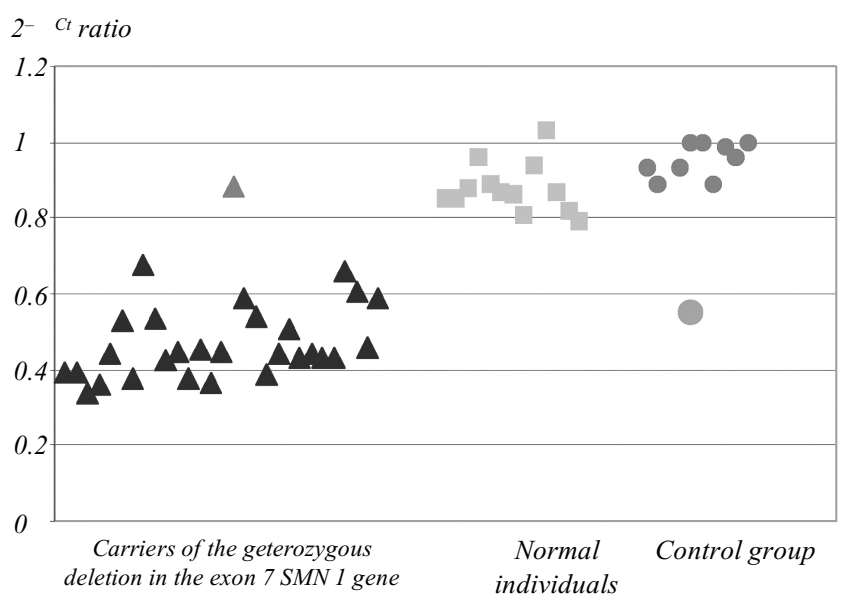

Fig. 3. $2^{-\Delta \Delta \mathrm{Ct}}$ values for the heterozygous carriers of the exon 7 SMN1 gene deletion $(\mathbf{A})$, normal individuals $(\mathbf{\square})$ and control group (๑)

of the parents of the SMA patient that are probably the carriers of the heterozygous deletion in the SMN1 gene (Fig. 1, lanes 4 and 5).

Using the developed quantitative assay the following results were obtained (Fig. 2, see inset).

The DNA samples of the patients with homozygous deletion show absence of the SMN1 amplification product (the amplification curve of the SMN1 gene product reached the threshold line only after 37 cycle and indicates a very low PCR efficiency) but the $A L B$ gene is being amplified (Fig. 2, $A$, see inset). The DNA samples with the heterozygous deletion in the SMN1 gene show the increase of $C_{t}$ value as compared with that of albumin (Fig. 2, B, see inset). The samples with 2 copies of the $S M N 1$ gene show nearly the same $\mathrm{Ct}$ value with the $A L B$ product (Fig. 2, $C$, see inset).

We have tested 42 control DNA samples from: 29 heterozygous carriers of the deletion in the exon 7 SMN1 gene, 13 normal individuals, which were previously analyzed using linkage analysis of 2AE9.1 (D5S557) and LAS96 (D5S681) polymorphic microsatellite loci, and also 10 individuals from the general population. The distribution of the $2^{-\Delta \Delta \mathrm{Ct}}$ ratio values of the analyzed samples are plotted in the Fig. 3. Among the heterozygous carriers of the exon 7 SMN1 gene deletion one sample had two copies. We suggest that this DNA sample has two copies in one chromosome and the deletion in another $(2+0$ ge- 
Real-Time PCR data of the SMN1 copy number quantification

\begin{tabular}{|c|c|c|c|c|c|}
\hline Gene & Patient status & Number of samples & $\begin{array}{c}2^{-\Delta \Delta C \mathrm{t}} \\
\text { Minimum-Maximum }\end{array}$ & $\begin{array}{c}\text { Mean } \pm \text { SD } \\
\text { Values }\end{array}$ & $\begin{array}{c}\text { Estimated copy } \\
\text { number }\end{array}$ \\
\hline \multirow[t]{3}{*}{$S M N 1$} & Homozygous deletion carrier & 10 & N. a. & N. a. & 0 \\
\hline & Heterozygous deletion carrier & 29 & $0.35-0.67$ & $0.475 \pm 0.091$ & 1 \\
\hline & Normal indvidual & 23 & $0.8-1.028$ & $0.909 \pm 0.068$ & 2 \\
\hline
\end{tabular}

N. a. - non available.

notype), such cases were described previously [14]. Two copies of the SMN1 gene in an heterozygous carrier could also be a result of the crossover of the alleles in the SMN1 gene region that can give false results using linkage analysis.

Among the individuals from the general population without SMA familial history $(n=10)$ one DNA sample appeared to have heterozygous deletion of the exon 7 SMN1 gene.

The range of the $2^{-\Delta \Delta \mathrm{Ct}}$ values for the DNA samples from patients with homozygous deletion, heterozygous carriers and normal individuals are presented in the Table.

We have calculated the Student's criterium for the $2^{-\Delta \Delta \mathrm{Ct}}$ means of heterozygous deletion carriers and normal individuals; $t=3.84, p>0.05$. It shows that there is no overlapping between $2^{-\Delta \Delta \mathrm{Ct}}$ values for the DNA samples from the SMN1 heterozygous deletion carriers and individuals without deletion. As opposed to the gene dosage analysis, in which the SMN2 gene forms heteroduplexes with the SMN1 gene [14] and makes the copy number detection of the SMN1 gene more complicated and inaccurate method, the proposed Real-Time PCR based approach specifically amplifies the exon 7 SMN1 gene only and the contribution of the SMN2 gene is minimal and does not affect the analysis. Therefore, this method can effectively differentiate the copy number of the exon 7 in the SMN1 gene.

Conclusions. The quantitative analysis of the SMN1 gene copy number using Real-Time PCR with SYBR Green was elaborated. This method was shown to be fast, sensitive and reliable. The results can be obtained within 3 hours and there is no need in postPCR processing, thus avoiding cross-con- tamination of the samples. Therefore, this method can be applied for SMA analysis in the molecular-genetic diagnostics as a basis for developing the specific test-system, and as well for prenatal and postnatal diagnostics, for SMA carriers screening programmes as a way of SMA prevention.

Acknowledgments. We are grateful to Prof. A. Polyakov and Prof. V. Baranov for the control DNA samples.

О. О. Соловйов, Г. Б. Лівшиць, С. С. Подлєсная, Л. А. Лівшииь

Застосування кількісної ПЛР у реальному часі для

молекулярно-генетичної діагностики спінальної

м'язової атрофії

Резюме

Мета. Мета роботи полягала у розробиі простого і надійного методу кількісного аналізу делеції 7-го екзону гена SMN1 за допомогою ПЛР у реальному часі з барвником-інтеркалятором SYBR Green, який можна використовувати в тест-системах для діагностики спінальної м'язової атрофії (СМА). Методи. Для розробки методу визначення кількості копій гена SMN1 застосовано підхід, який базується на порівнянні параметрів ампліфікації досліджуваного зразка ДНК та зовнішнього стандарту (ген альбуміну). Для підтвердження розробленого методу проаналізовано зразки ДНК 10 паџіентів із СМА (гомозиготна делеція 7-го екзону гена SMN1), 42 контрольних зразки ДНК (від 29 гетерозиготних носіїв делещії 7-го екзону гена SMN1 і 13 індивідуумів без делеиііï), які вивчено методом зчеплення з поліморфними мікросателітними маркерами $2 A E 9.1$ (D5S557) i LAS96 (D5S681), а також зразки від 10 індивідуумів з контрольної популяиії. Обробку результатів проводили за допомогою стандартного методу Лівака (метод $2^{-\Delta \Delta C t}$ ). Результати. Середнє значение зі стандартною похибкою показника $2^{-\Delta \Delta t}$ для гетерозиготних носіїв делечії 7-го екзонугена SMN1 становить 0,475 \pm 0,091, для нормальних контролів 0,909 \pm 0,068. Встановлено відсутність перекривання результатів аналізу для гетерозиготних носіїв делеції і нормальних контролів $(t=3,84, p>0,05)$. Висновки. Розроблений метод може бути придатним для аналізу СМА у програмах молекулярно-генетичного тестування, а також як компонент тестсистем для діагностики СМА.

Ключові слова: спінальна м'язова атрофія, ген SMN1, делеція, ПЛР у реальному часі. 


\section{А. А. Соловьев, А. Б. Лившии, С. С. Подлесная, Л. А. Ливщии}

Применение количественной ПЦР в реальном времени для молекулярно-генетической диагностики спинальной мышечной атрофии

Резюме

Цель. Цель работы состояла в разработке простого и надежного метода количественного анализа делечии 7-го экзона гена SMN1 с помощью ПЦР в реальном времени с интеркалирующим красителем SYBR Green, который можно использовать в тест-системах для диагностики спинальной мымечной атрофии (СМА). Методы. Для разработки метода подсчета количества копий гена SMN1 применен подход, основанный на сравнении параметров амплификации исследуемого образиа ДНК и внешнего стандарта (ген альбумина). Для подтверждения разработанного метода проанализированы образиь ДНК 10 пациентов со СМА (гомозиготная делеция 7-го экзона гена SMN1), 42 контрольных образиа ДНК (от 29 гетерозиготных носителей делеиии 7-го экзона гена SMN1 и 13 индивидуумов без делеции), изученных методом сиепления с полиморфными микросателлитными маркерами 2AE9.1 (D5S557) и LAS96 (D5S681), а также образиы от 10 индивидуумов из контрольной популяции. Обработку результатов проводили с помощью стандартного метода Ливака (метод $2^{-\Delta \Delta C t}$ ). Результаты. Среднее значение со стандартной ошибкой показателя $2^{-\Delta \Delta C t}$ для гетерозиготных носителей делеции 7-го экзона гена SMN1 составляет 0,475 \pm 0,091, для нормальных контролей $-0.909 \pm$ \pm 0.068 . Установлено отсутствие перекрывания результатов анализа для гетерозиготных носителей делеиии и здоровых индивидуумов $(t=3,84, p>0,05)$. Выводы. Разработанныйметод может быть использован для анализа СМА в программах молекулярно-генетической диагностики, а также как компонент тест-систем для диагностики СМА.

Ключевые слова: спинальная мышечная атрофия, ген SMN1, делеция, ПЦР в реальном времени.

\section{REFERENCES}

1. Ekshiian A. Iu., Livshits L. A., Bychkova A. M., Afanas'eva N. A., Bariliak I. R. A molecular genetic analysis of spinal muscular atrophy (SMA) in families at high risk from different regions of Ukraine // Cytology and Genetics.-1997.-31, N 6.-P. 75-81.

2. Munsat T. L., Davies K. E. International SMA consortium meeting // Neuromuscul. Disord.-1992.-2, N 5-6.-P. 423428.

3. Lefebvre S., Burglen L., Reboullet S., Clermont O., Burlet P., Viollet L., Benichou B., Cruaud C., Millasseau P., Zeviani M., Le Paslier D., Frezal J., Cohen D., Weissenbach J., Mun- nich A., Melki J. Identification and characterization of a spinal muscular atrophy-determining gene // Cell.-1995.-80, N 1.- P. 155-165.

4. Melki J., Lefebvre S., Burglen L., Burlet P., Clermont O., Millasseau P., Reboullet S., Benichou B., Zeviani M., Le Paslier D., Cohen D., Weissenbach J., Munnich A. De novo and inherited deletions of the $5 \mathrm{q} 13$ region in spinal muscular atrophies // Science.-1994.-264, N 5164.-P. 1474-1477.

5. Lorson C. L., Hahnen E., Androphy E. J., Wirth B. A single nucleotide in the $S M N$ gene regulates splicing and is responsible for spinal muscular atrophy // Proc. Nat. Acad. Sci. USA.-1999.-96, N 11.-P. 6307-6311.

6. Monani U. R., Lorson C. L., Parsons D. W., Prior T. W., Androphy E. J., Burghes A. H., McPherson J. D. A single nucleotide difference that alters splicing patterns distinguishes the $S M A$ gene $S M N 1$ from the copy gene $S M N 2$ // Hum. Mol. Genet.-1999.-8, N 7.-P. 1177-1183.

7. Livshits G. B., Hryshchenko N. V., Podlesna S. S., Ekshiian A. $I u$. Molecular-genetic analysis of spinal muscular atrophy in Ukrainian patients // Int. Neurol. J.-2009.-26, N 4.-P. 20-22.

8. Ogino S., Leonard D., Rennert H., Wilson R. B. Spinal muscular atrophy genetic testing experience at an academic medical center // J. Mol. Diagn.-2002.-4, N 1.-P. 53-58.

9. McAndrew P. E., Parsons D. W., Simard L. R., Rochette C., Ray P. N., Mendell J. R., Prior T. W., Burghes A. H. Identification of proximal spinal muscular atrophy carriers and patients by analysis of $S M N T$ and $S M N C$ gene copy number // Am. J. Hum. Genet.-1997.-60, N 6.-P. 1411-1422.

10. Ogino S., Leonard D. G. B., Rennert H., Gao S., Wilson R. B. Heteroduplex formation in $S M N$ gene dosage analysis // J. Mol. Diagn.-2001.-3, N 4.-P. 150-157.

11. Maniatis T., Fritsch E. F., SambrookJ. Molecular cloning: a laboratory manual.-New York: Cold Spring Harbor Lab. publ., 1982.-545 p.

12. Kim S. W., Lee K. S., Jin H. S., Lee T. M., Koo S. K., Lee Y. J., Jung $S$. C. Rapid detection of duplication/deletion of the $P M P 22$ gene in patients with Charcot-Marie-Tooth disease type $1 \mathrm{~A}$ and hereditary neuropathy with liability to pressure palsy by real-time quantitative PCR using SYBR Green I dye // J. Korean. Med. Sci.-2003.-18, N 5.-P. 727-732.

13. Livak K. J., Schmittgen T. D. Analysis of relative gene expression data using real-time quantitative PCR and the $2^{-\Delta \Delta C T}$ method // Methods.-2001.-25.-P. 402-408.

14. Chen K. L., Wang Y. L., Rennert H., Joshi I., Mills J. K., Leonard D. G., Wilson R. B. Duplications and de novo deletions of the SMNt gene demonstrated by fluorescence-based carrier testing for spinal muscular atrophy // Am. J. Med. Genet.1999.-85, N 5.-P. 463-469.
UDC $575.11+577.21$

Received 22.07.09 
Figure to article by Soloviov O. O. et al.
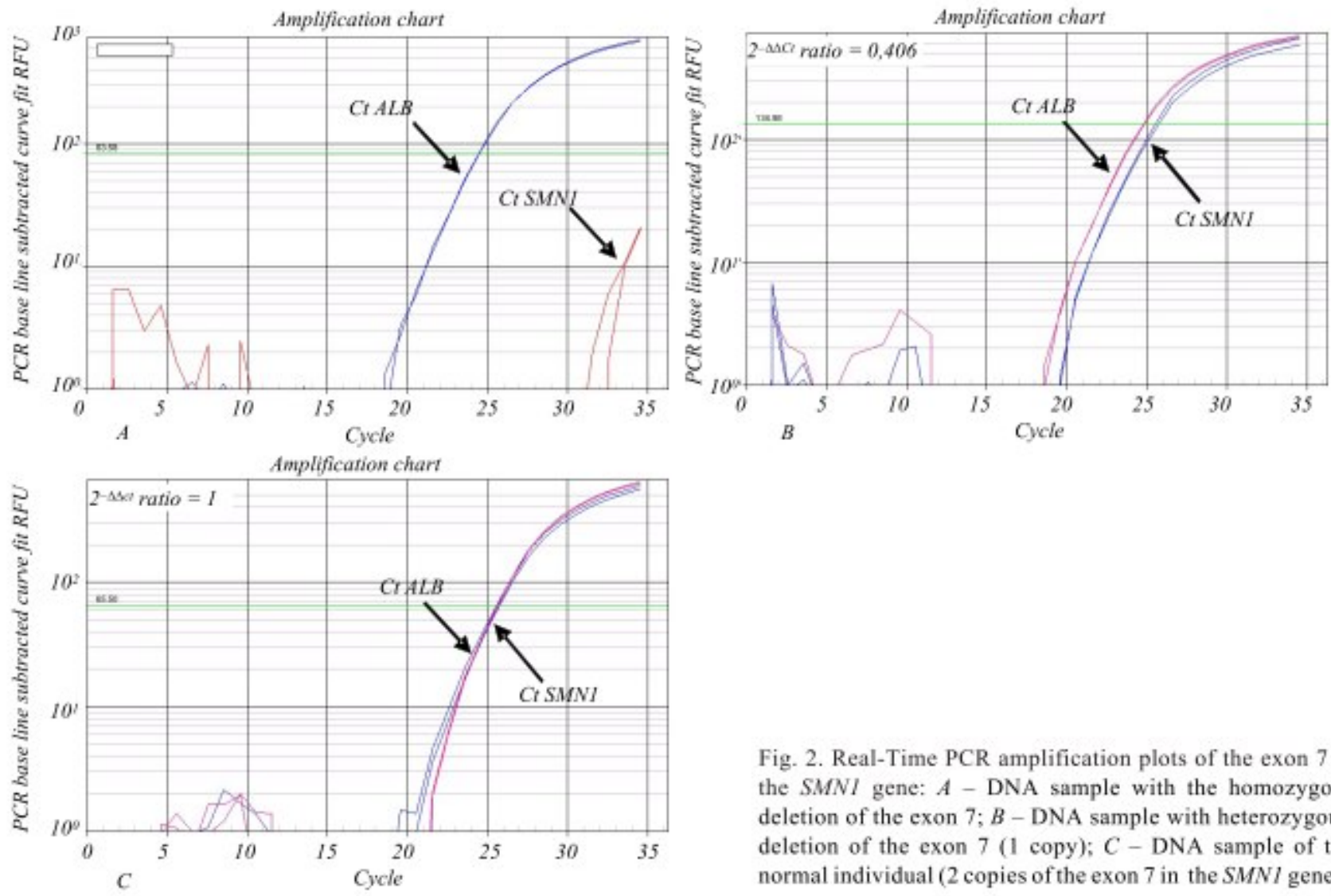

Fig. 2. Real-Time PCR amplification plots of the exon 7 in the $S M N I$ gene: $A$ - DNA sample with the homozygous deletion of the exon $7 ; B$ - DNA sample with heterozygous deletion of the exon 7 ( 1 copy); $C$ - DNA sample of the normal individual ( 2 copies of the exon 7 in the SMN/ gene) 